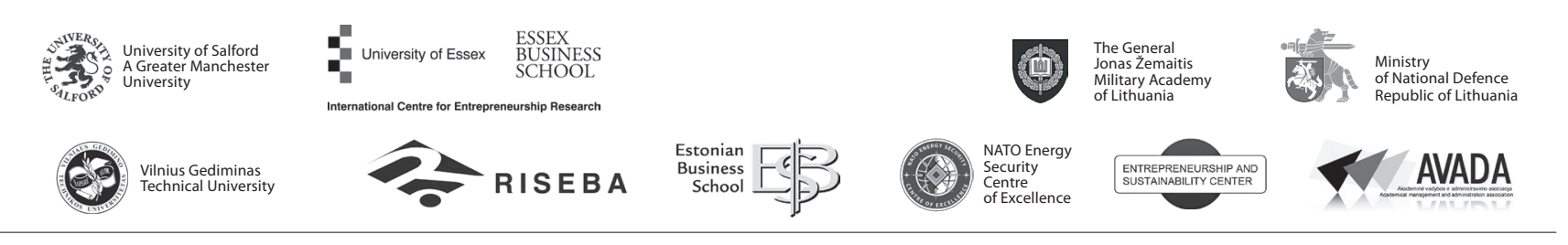

\author{
JOURNAL OF SECURITY AND SUSTAINABILITY ISSUES \\ ISSN 2029-7017 print/ISSN 2029-7025 online \\ 2018 June Volume 7 Number 4 \\ https://doi.org/10.9770/jssi.2018.7.4(4)
}

\title{
TOWARDS SECURITY OF PERFORMANCE: WHISTLEBLOWING AS MANAGEMENT TOOL
}

\author{
Mario Bogdanović ${ }^{1}$, Stanislav Filip ${ }^{2}$ \\ ${ }^{1}$ Serdara Vučkovića 16, Sinj, Croatia \\ ${ }^{2}$ School of Economics and Management in Public Administration, Bratislava, Slovak Republic, \\ Furdeková 16, 85104 Bratislava, Slovak Republic \\ Emails: ${ }^{1}$ mbogdan2011@gmail.com, ${ }^{2}$ stanislav.filip@vsemvs.sk
}

Received 20 February 2018; accepted 10 June 2018

\begin{abstract}
This study examines and compares the attitude of management students in Croatia and Slovakia towards whistleblowing in a sample of 121 master students of business ethics at the Faculty of Economics University in Split, Croatia, and 169 master students from University of Bratislava, Slovakia. The three measurement instruments include whistleblowers' attitudes (3 items), whistleblowing attitudes ( 2 items) and potential types of whistleblowing reactions ( 8 items), i.e. external reactions (4 items) and internal reactions (4 items). The results of the study indicated a positive attitude toward whistleblowing and whistleblowers in both student groups. It is also found that Croatian students exhibited more positive attitude towards whistleblowers than Slovakian students. Also, Croatian students showed more proneness to react in a whistleblowing situation - both inside the organization and externally via media. These conclusions suggest that the sense of moral duty to blow the whistle, as well as less fear of the potential consequences, is stronger in Croatian students. The results may be of practical use to managers who can benefit from whistleblowing while keeping in mind that whistleblowing can't be avoided and that punishing whistleblowers seems to be a bad managerial practice.
\end{abstract}

Keywords: performance security; whistleblowing; management tool; internal and external whistleblowing; business ethics; ethical business culture

Reference to this paper should be made as follows: Bogdanović, M.; Filip, S.; 2018. Towards security of performance: whistleblowing as management tool, Journal of Security and Sustainability Issues 7(4): 657-673. https://doi.org/10.9770/jssi.2018.7.4(4)

JEL Classification: H 120, K420

\section{Introduction}

Management should have keen interest in avoiding illegal, immoral or illegitimate practices (in order to avoid corporate scandals) by encouraging employees to report unethical conduct internally ${ }^{1}$, so it can be addressed quickly and be prevented from growing into a larger crisis (Mayer at al., 2013, p. 89; Luzgina, 2017; Kordík, Kurilovská, 2017). Also by means of internal reporting, external reporting should be avoided. Reporting about different kind of organizational misconduct is covered by the term of whistleblowing.

Originally the term whistleblowing originates from the practice of English policemen who blew their whistle when they observed a crime. The blowing of a whistle alerted other law enforcement officers and the general

\footnotetext{
1 In the great mayority of cases employees tell someone within the organization and don't want to cause any bad publicity for the organization - thus is called internal reporting or internal whistleblowing. When organizations punish or discourage internal reporting, bad practices typically get worse, until someone often motivated by conscience - feels they must notify the press, government agency or other external institutions - this is known as external whistleblowing/reporting, and it can mean serious problems for the organization (http://www. ethicalsystems. org/content/whistleblowing. Available on 13. June 2017.).
} 
public that a crime was being committed (Dasgupta and Tavakoli, 2010). In organizational life, the most commonly accepted definition of whistleblowing is "the disclosure by organization members (former or current) of illegal, immoral and illegitimate practices under the control of their employers to persons and organizations that may be able to effect action" (Near and Miceli, 1985). It represents an ethicist's version of optical illusion, as from one perspective it is the ultimate act of justice and serving to right a wrong, while from another point of view it is the ultimate breach and a grave betrayal of the organization (Dungan, Waytz and Young, 2015).

Whistleblowing is for businesses, organizations and management an interesting but complex phenomenon that appears to be occurring with greater frequency throughout the world. Although employees are generally reluctant to report internally because they fear retaliation for reporting or believe such efforts will be futile (MesmerMagnus and Viswesvaran, 2005), and the same is valid in the case of external reporting - such behavior can have significant positive and negative consequences on organizational and social functioning. In numerous examples, due to external whistleblowers' activity, the public get acquainted with ethical and legal abuses in business and governmental organizations.

Whistleblowers teach about violation of law, misuse of public funds, falsifying documents, mismanagement, misuse of public facilities, questionable research activities, excessive spending, censorship (Soeken and Soeken, 1986; Kordík, Kurilovská, 2017), unsafe products, corruption, waste of resources (material, financial, human), or ecological misuse (Luzgina, 2017). From whistleblowers, we learn about the "dark side" of business, organizations and management in numerous existing forms. The most common types of wrongdoing which can provoke whistleblower behavior are presented in table 1.

Table 1. Types of organizational wrongdoing

\begin{tabular}{|c|l|}
\hline Category & \multicolumn{1}{|c|}{ Constituents } \\
\hline Stealing & $\begin{array}{l}\text { Stealing of funds, stealing of property, accepting bribes/kickbacks, use of an official position for personal } \\
\text { benefit, unfair advantage to contractor, and employee abuse of office }\end{array}$ \\
\hline Wasting & Wasting of organizational assets, wasting social benefits \\
\hline Mismanagement & Management cover-up of poor performance and making false projections of performance \\
\hline Safety problems & Unsafe or non-compliant products and unsafe working conditions \\
\hline Sexual harassment & Unwelcome sexual advances/requests for sexual favors and verbal/physical contact of sexual nature \\
\hline Unfair discrimination & Discrimination based on race, sex, religion, etc. \\
\hline Legal violations. & Violations of law, etc. \\
\hline
\end{tabular}

Source: Dasgupta and Ankit (2010).

Employees are usually among the first to learn about unfair practices and can point them out, therefore use of whistleblowing means active notification of a particular unfair practice that takes place within the workplace (Caha and Urban, 2017). The basic question in evaluating the whistleblowers activity is: "Are whistleblowers betrayers or heroes?" There are two opposite reasoning: whistleblowing can be seen as a negative or a positive activity (Tavakoli et al., 2003).

From the point of view of those who are absolutely loyal to governments, corporations and in general to the organizations which tend to hide exceeding, bypassing or disregarding of laws or standards, whistleblowers are betrayers. In some cultures, social norms say that it is disloyal to the organization and management to blow the whistle, and in contrary conformity and obedience to hierarchy is highly valued. From such a narrow perspective, the wrongdoer is in fact the whistleblower, not his management/other employee who commits any kind of wrongdoing mentioned in Table 1. Such a cultural perspective considers a whistleblower as an "evil" because of his/her "dark motivation" resulting from either intention for revenge against his organization, or having some financial benefits from whistleblowing and perhaps reinstatement of employment (e.g. manipulation of some kind or blackmailing in order to achieve better organizational position). In fact whistleblowers are more likely then inactive to be highly payed, have high job performance, hold supervisory or professional status and have the role responsibility to report wrongdoing and the knowledge of how to do so (http:/www. ethicalsystems.org/content/ 
whistleblowing. Available on 13. June 2017.). From the economic point of view, (external) whistleblowing is an undesirable course of action because it could confound all the marketing and PR efforts and seriously damage the image of the organization (Tavakoli et al., 2003). From the perspective of the second group of people who fully obey and respect the law and social norms, "whistleblowers are heroes." They are loyal to the organization (to its mission statements, values, goals, etc.) since they are ready to inform and fight against any deviation from the corporation's own statements and values. Although whistleblowing could be considered as a step against managers or employees, it should not be seen as an act of damaging the corporate image but as an act of courage and support of the organization in a broader perspective. No employee is bound to be loyal towards any individual or group within an organization who violates the mission, goals and values of the organization (Vandekerchove and Commers, 2004.). A whistleblower could be seen as an altruistic person with unselfish concerns about the well-being of others to avoid the wrongdoing which harms the interests of the organization, its consumers, co-workers and the society in general (Arnold and Ponemon, 1991; Vinten, 2000 according Dasgupta and Ankit, 2010). Researcher also found another whistleblower typologies based on goals, motivations and context, i.e. altruist, avenger, organization men, alarmist and bounty hunter type (Heumann at al., 2013).

So, from the business ethics point of view, we can conclude that whistleblowers are dominantly heroic individuals who, in spite of severe resistance of the organization/society and discouragement (Miceli at al., 2008, Grimsley, 2000, Ridge, 2000) protest against misbehavior in the attempt to fix it. Internal and external whistleblowers have the potential to be teachers (counsellors) and direction-proposers in institutional and systemic changes. Although both laws (which prescribe what should not be done) and ethical codes (which prescribe that something that is incorrect should not even be considered) exist when they are violated, whistleblowers help to avoid and fix any socially inappropriate behavior.

Also, although whistleblowers can provoke unpleasantness in the short-term, they support the organizational ideals and better system from a long-term sustainable socio-economic perspective. This is appreciated by multiple multinational enterprises (MNEs). Some of them have established special departments where whistleblowers may share their reports. Others have established ethics codes, which encourage employees to contact the organization's legal counsel in case of any illegal or unethical activities. In fact, a study of international codes of conduct for MNEs indicates a substantial agreement on the moral duties of MNEs (Tavakoli et al., 2003). Positive attitudes towards whistleblowing may help to predict or explain whistleblowing behavior, and prevent greater organizational damages. Because of the risk they face, whistleblowers should be awarded in the same manner as entrepreneurs are awarded for their business risk taking since they represent a cardinal factor of growth and development of organizations and social systems. This is the suggestion of whistleblowers association in Croatia, i.e. "to the whistleblower the reward in the amount of $10 \%$ of the damage which he prevent" (Večernji list, 2014).

Whistleblowers compared with inactive observers tend to have good job performance, to be more highly educated, to hold higher-level or supervisory positions, to score higher on tests of moral reasoning, and to value whistleblowing in the face of unethical behavior (Sims and Keenan, 1998, Near and Miceli; 1996, Miceli and Near; 1984, Brabeck, 1984) suggest that they are well educated, dedicated to their job, and good and reliable employees. Many of them are individuals with high working performance who feel invited to report about wrong doing in organization according to their own moral (moral ideology) ${ }^{2}$, and in general they believe that they are expected to blow the whistle in case of any misbehavior (Ottensmeyer and McCarty, 1996, 424-434).

Although whistleblowers want to improve the working environment and organizational performance due to their own personal beliefs in good, they regularly experience retaliation and animosity from their supervisors, peers and colleagues (Soaken and Soaken, 1986). They are also usually exposed to psychological pressure in the form of job ostracism (Wu et al., 2012). Courage to tell the unpleasant truth is often dangerous, but in fact it helps to develop the organization in a positive way ${ }^{3}$ (Lučić, 2013). Anyway an employee may however face

\footnotetext{
2 Today in organizational life, many moral ideologies exist; the most famous are: idealism, relativism, Machiavellianism, golden ethical rule, narcism, utilitarianism, cost-benefit analysis and altruism (cf. Chudziska-Czupala, 2013).

3 Paraphrased from the great Croatian writers Miroslav Krleža and Ivo Andric (Nobel prize bearer) „Lie is a religion of master and slaves, the truth is religion of strong and free human beings. "
} 
various ethical dillemas in such a situation, e.g. should be disloyal to their colleagues, line manager, general management or even employer, putting their own position at risk, on the one hand, or it is more important to protect organizational or public interest, on the other hand (cf. Caha and Urban, 2017).

Organizations and management do not react properly when ignoring, lying or even maltreating whistleblowers. Organizational performance and respect of ethics can be improved only when we are aware of drawbacks and weaknesses in our team and its behavior. And in case we don't have any other measures to recognize any misbehavior, whistleblowers could be one of the solutions. It could be surprising that in spite of very bad treatment of whistleblowers (e.g. repression and retaliation), only in the US there are several hundred thousand whistleblowers in all the spheres of organizational life (Ottensmeyer and McCarty, 1996, 427). So, it is a real and frequent phenomenon which needs to be researched in more detail. In Croatia, there has not been any research about whistleblowing done, although reality shows that it is not a rare phenomenon. The practice in Croatia shows that whistleblowing and whistleblowers are, in reality, condemned; they are treated extremely badly although in many cases they pointed out criminal and unethical acts which could accelerate organizational and social development. One very real and current problem in Croatia is corruption and theft. On 28 October 2013, a bill concerning protection of denunciators of anomalies (i.e. whistleblowers protection) was introduced in Croatia. The intention of this bill was to discourage the management from revengeful behavior against denunciators of anomalies, change the "climate of fear", stimulate socially responsible behavior, change the negative perception of whistleblowers, narrow the space for corruption and make a contribution in building a more righteous society (suggestion of Dr. Dražen Gorjanski).

To which extent are whistleblowers important in illuminating criminal acts, e.g. corruption, we may see in the research about corruption. Due to whistleblowing activities, $43 \%$ of corruption was uncovered whilst due to the police investigations this figure was just about 2-3\%. Whistleblowers are also extremely efficient in drawing attention to very different anomalies. When informing about such anomalies, there are, on average, 20 other active individuals (potential but inactive whistleblowers) who will follow them. Thus, we may consider it as an evidence of an economic adequacy of whistleblowing in battle against corruption when $1 \$$ invested into this purpose (whistleblowers support) results in $8 \$$ yield (prevented damage) (Večernji list, 2014), (Vasilova, 2015), (Kabat, Filip and Filipová, 2016). Also according Global economic survey (2016) $23 \%$ of all the respondents that had faced serious economic crime stated that the behavior had been revealed by means of a notification system (an anonymous line, helpline, etc.) or by notification inside the organization. Similarly, a survey conducted by KPMG (2008) showed that $19 \%$ of the 568 analyzed cases of economic crime were revealed by whistleblowers (Caha and Urban, 2017). There are many ways to understand why CEOs or supervisors in general do not accept or even sanction whistleblowers. Considering different power related frameworks, whistleblowing can be understood as a two-way process, where reporting represents an attempt to elevate the whistleblower's own internal power over a dominant coalition in the organization and thus singular or repeated negative and retaliatory actions can be experienced within the organization against such initiative (Bjørkelo, 2013).

To achieve a higher level of satisfaction of organizational and social interests, we pursued research on attitudes of the most propulsive population, i.e. Master students of management who may in the future restructure the social attitudes toward whistleblowing. This paper deals with exploration of different attitudes toward whistleblowing among master students of management in Croatia and Slovakia, and according to the obtained results, we propose measures to create such an ethical climate which will make external whistleblowing unnecessary. The research questions (problems) are defined as follows:

- What is the actual attitude of students of management towards whistleblowers, whistleblowing, and their potential whistleblowers' reaction?

- What are the differences in the students' attitude towards whistleblowing and whistleblowers, potential whistleblowers' reaction with regard to gender?

- What are the differences in the students' attitude towards whistleblowing and whistleblowers, potential whistleblowers' reaction with regard to organizational membership? 


\section{Methodology}

\section{Measurement instruments}

The research first studied attitudes to whistleblowing of Slovakian and Croatian students and then performed a comparative analysis of the two groups. To understand the status quo and provide conclusions about potential future attitudes toward whistleblowing, it is used a questionnaire with 13 items divided into four areas of research interest:

1. Attitudes to whistleblowers - 3 items;

2. Attitudes to whistleblowing (ethical correctness) - 2 items;

3. Whistleblowers' reaction - outside the organization (external) - 4 items;

4. Whistleblowers' reaction - inside the organization (internal) - 4 items.

The questionnaire used a 5 degree Likert-type response format according to the following scores:

- To measure attitudes toward whistleblowers and whistleblowing, we used the following response scale: 1. I strongly disagree; 2. I disagree; 3 . I do not agree nor disagree; I agree; 5. I strongly agree.

- To measure the whistleblowers' reaction, we used the following response scale: I will never act in such a way; 2. I will not act in such a way; 3 . I am not sure if I would act in such a way; 4. I believe I would act in such a way; 5. I am sure that I will act in such a way.

The attitude questionnaire described some ethical attitudes about whistleblowers and the whistleblowing phenomenon. The reaction questionnaire described reactions in the whistleblowing situations in terms of what would the interviewee react like (external and/or internal) if he had the intention to "blow into the whistle". The original questionnaire is provided in the appendix. The comparison of metric characteristics obtained on both the Slovakian $(\mathrm{N}=169)$ and Croatian student sample $(\mathrm{N}=121)$ are provided in table 1.

Table 2 suggests that all the tested variables are sufficiently reliable (Cronbach alpha score equal or greater than 0.60). In Slovakian sample, external whistleblowers' reaction has been determined as of the lowest reliability (Alpha $=0.62$ ), however according to DeVellis $(1991)^{4}$, it can still be treated as acceptably reliable, while in Croatian students, with the same Cronbach Alpha score, attitude to whistleblowers has emerged as the least reliable item. Attitude to whistleblowing has shown to be the most reliable variable in both samples, with Cronbach Alpha result of 0.81 and 0.83 respectively for Slovakian and Croatian students, which is categorized as excellent reliability. In both students' samples, attitude towards whistleblowing in general has been more stable than attitude to whistleblowers. The rest of the summary variables' Cronbach alpha score suggests their reliability is very good.

Table 2. Basic psychometric norms achieved on both Slovakian and Croatian student sample for the key whistleblowing variables

\begin{tabular}{|l|c|c|c|c|c|c|}
\hline \multicolumn{1}{|c|}{ Variable name } & \multicolumn{3}{|c|}{ Slovakian sample } & \multicolumn{3}{c|}{ Croatian sample } \\
\hline & Mean & $\begin{array}{c}\text { Std. } \\
\text { deviation }\end{array}$ & $\begin{array}{c}\text { Cronbach } \\
\text { alpha }\end{array}$ & $\begin{array}{c}\text { Std. } \\
\text { Croan } \\
\text { deviation } \\
\text { alpha }\end{array}$ \\
\hline Attitude to whistleblowers (N=3 items) & 3.44 & 0.80 & 0.70 & 3.75 & 0.78 & 0.62 \\
\hline Attitude to whistleblowing (N=2 items) & 3.71 & 0.90 & 0.81 & 3.79 & 0.95 & 0.83 \\
\hline $\begin{array}{l}\text { Total attitude to whistleblowers and whistleblowing } \\
\text { (N=5 items) }\end{array}$ & 3.55 & 0.72 & 0.77 & 3.73 & 0.75 & 0.77 \\
\hline External whistleblowers' reaction (N=4 items) & 2.66 & 0.89 & 0.62 & 3.16 & 0.85 & 0.79 \\
\hline Internal whistleblowers' reaction (N=4 items) & 3.16 & 0.88 & 0.78 & 3.40 & 0.98 & 0.80 \\
\hline $\begin{array}{l}\text { Total (external and internal) whistleblowers' reaction } \\
\text { (N=8 items) }\end{array}$ & 2.91 & 0.70 & 0.71 & 3.28 & 0.69 & 0.74 \\
\hline Total scale (N=13 items) & 3.16 & 0.60 & 0.78 & 3.47 & 1.12 & 0.80 \\
\hline
\end{tabular}

Source: Research results

4 According DeVellis (1991) the Cronbach alpha reliability should be interpreted as follow: $<0,60=$ not acceptable; 0,60-0,65=borderline (can be treated as acceptable); $0,65-0,70=$ acceptable; $0,70-0,80=$ very good; $0,80-0,90=$ excellent; $>0,90=$ the scale should be shortened. 
The results presented above suggest that the Slovakian interviewees are more consistent in their attitude towards whistleblowing as a phenomenon (alpha $=0,81)$ than to the individual whistleblowers (alpha $=0,71)$. The same verdict can be noticed in the Croatian sample, which are also significantly more consistent in their attitude to whistleblowing in general (alpha $=0,83$ ) than to whistleblowers as individuals (alpha $=0,62$ ). They also demonstrate that the interviewees from both samples are significantly more consistent in the internal whistleblower's actions (alpha $=0,78-0,80$ ) they would have taken if they were in a situation to blow the whistle than the reaction outside the organization (alpha $=0,71-0,74)$.

Another noticeable difference between the two student samples can be marked in external whistleblowers' reaction, as Croatian interviewees are considerably more consistent in their attitudes $($ alpha $=0,79)$ than their Slovakian colleagues (alpha $=0,62$ ). Tables 3 and 4 display the intercorrelations matrix between each of the 13 items in the questionnaire for both samples to inspect whether any of the items are overlapping.

Table 3. Intercorrelation between the questionnaire items for the Slovakian student sample

\begin{tabular}{|c|c|c|c|c|c|c|c|c|c|c|c|c|c|}
\hline & 1 & 2 & 3 & 4 & 5 & 6 & 7 & 8 & 9 & 10 & 11 & 12 & 13 \\
\hline 1 & 1 & & & & & & & & & & & & \\
\hline 2 & ,438 & 1 & & & & & & & & & & & \\
\hline 3 & .510 & .364 & 1 & & & & & & & & & & \\
\hline 4 & .371 & .163 & .434 & 1 & & & & & & & & & \\
\hline 5 & .388 & .146 & .499 & .676 & 1 & & & & & & & & \\
\hline 6 & .107 & .107 & .147 & -.060 & .092 & 1 & & & & & & & \\
\hline 7 & .175 & .277 & .207 & .116 & .187 & .371 & 1 & & & & & & \\
\hline 8 & .034 & .175 & .152 & -.014 & .130 & .452 & .450 & 1 & & & & & \\
\hline 9 & .198 & .136 & .197 & .085 & .199 & .389 & .223 & .194 & 1 & & & & \\
\hline 10 & .219 & .113 & .306 & .310 & .349 & .081 & .322 & .104 & .164 & 1 & & & \\
\hline 11 & .081 & .083 & .110 & .066 & .127 & .107 & .275 & .249 & .161 & .407 & 1 & & \\
\hline 12 & .163 & .138 & .221 & .257 & .309 & .033 & .328 & .214 & .160 & .543 & .439 & 1 & \\
\hline 13 & .164 & .084 & .171 & .387 & .315 & -.108 & .251 & .003 & .041 & .569 & .289 & .630 & 1 \\
\hline
\end{tabular}

Source: Research results

Table 4. Intercorrelation between the questionnaire items for the Croatian student sample

\begin{tabular}{|c|c|c|c|c|c|c|c|c|c|c|c|c|c|}
\hline & 1 & 2 & 3 & 4 & 5 & 6 & 7 & 8 & 9 & 10 & 11 & 12 & 13 \\
\hline 1 & 1 & & & & & & & & & & & & \\
\hline 2 & .198 & 1 & & & & & & & & & & & \\
\hline 3 & .358 & .507 & 1 & & & & & & & & & & \\
\hline 4 & .243 & .459 & .431 & 1 & & & & & & & & & \\
\hline 5 & .265 & .414 & .443 & .706 & 1 & & & & & & & & \\
\hline 6 & .069 & .279 & .233 & .234 & .350 & 1 & & & & & & & \\
\hline 7 & .075 & .085 & .167 & .225 & .218 & .487 & 1 & & & & & & \\
\hline 8 & .186 & .206 & .243 & .340 & .368 & .534 & .340 & 1 & & & & & \\
\hline 9 & .104 & .161 & .147 & .279 & .410 & .550 & .398 & .558 & 1 & & & & \\
\hline 10 & .300 & .229 & .258 & .208 & .260 & .161 & .121 & .069 & .129 & 1 & & & \\
\hline 11 & .282 & .103 & -.012 & .194 & .249 & .126 & .057 & .054 & .186 & .571 & 1 & & \\
\hline 12 & .268 & .013 & .021 & .023 & .073 & .163 & .242 & .039 & .098 & .385 & .478 & 1 & \\
\hline 13 & .246 & -.034 & .085 & -.072 & -.050 & -.022 & .104 & -.071 & -.048 & .451 & .449 & .657 & 1 \\
\hline
\end{tabular}

Source: Research results 
All the items have shown relatively low to medium intercorrelations which implies they can be considered pure enough to be used in achieving the objective of the research. Concretely the most of highest inter-correlations between items are below $r=0,60$, only two are above (i.e. $r=0,676$ and $r=0,706$, inter-correlations between the item 4 and 5 in the both samples - Slovak and Croatian sample respectively), so there is enough unexplained variance to treat each of measured item as enough independent, therefore such overlapping can be treated as tolerable.

\section{Subjects}

The research on Croatian students was conducted in mid-December 2014, on a sample of 121 full time students of management during the first year of their master's degree studies (fourth year of integral study) at the Faculty of Economics, University of Split, Croatia (Bogdanović and Tyll, 2016). The students were attending the mandatory course of Business Ethics. From a total of 121 subjects, 84 were female and 37 male, with an age spread from 22 to 48 years $(22-25$ years $85 \%$; 26-29 years $9.2 \%$; and 30-48 years 5.8\%). 63 of them had work experience, while 58 had not. 5 students were married, 116 were single.

The research on Slovakian sample was performed in Jun $2016^{5}$ on a sample of 169 students of management during the first year of their master's degree studies at the School of Economics, and Management in Public Administration in Bratislava of the Slovak Republic, of which 117 were female and 52 were male students, with an age spread from 21 to 59 years old $(21-25$ years $67.4 \%$; $26-29$ years $8.9 \%$; $30-40$ years $17.8 \%$; and 41 59 years 5.9\%). 140 students had work experience and 29 didn't have any work experience. 33 students were married, while the rest 136 were single or unmarried.

\section{Procedure}

Prior to the research, all the interviewed students were instructed about and familiarized with the type, as well as the objective of the conducted research. They were asked for their approval to be included in this research. Only the students who accorded to participate were included into the research. The questionnaires were filled out anonymously within approximately five minutes. The collected data was processed by IBM SPSS statistical software package.

\section{Results}

\section{General remarks on basic descriptive results for all the items}

The basic descriptive statistics, providing answers about crucial questions on whistleblowing and whistleblowers for both Slovakian and Croatian students, is presented in table 5.

The table indicates existence of a generally positive attitude to whistleblowing (items 4 and $5 ; \mathrm{M}>3.50$ ) in both samples. This conclusion is strengthened by the fact that mode for both items is positive (Mode $\geq 4$ ). Attitudes towards whistleblowers (items 1-3) and their internal reactions (items 10-13) are dominantly positive (Mode $>=3$ ) in both student samples, with Slovakian students grading all the items regarding attitude to individual whistleblowers slightly lower than their Croatian colleagues.

This difference can be explained by the bad experiences about the consequences of the whistleblowers suffered in publicly best-known cases of whistleblowing as well as negative media attention around it and difficulties in finding a new job afterwards, which seems to have influenced the Slovaks stronger than the Croatian students.

5 During the teaching and research stay in Slovakia in summer semester 2015./2016. academic year one of the author. 
Attitude to external whistleblowers' reactions (items 6-9) is even less positive, as it is between neutral (Mode=3 for items 6 and 8) and slightly negative (Mode=2 for item 9) for Slovakian sample, and neutral for Croatian students, with modes being dominantly neutral $($ Mode $=3$ ) on both sides. These results can also be due to negative experiences of individual whistleblowers in well-known public whistleblowing cases, as well as the negative repercussions linked to it.

Table 5. Basic descriptive statistics for all the questionnaire items on both Slovakian and Croatian student sample

\begin{tabular}{|l|c|c|c|c|c|c|}
\hline \multicolumn{1}{|c|}{ Item } & \multicolumn{3}{|c|}{ Slovakian sample } & \multicolumn{3}{c|}{ Croatian sample } \\
\hline One & Mean & Std. Deviation & Mode & Mean & Std. Deviation & Mode \\
\hline Two & 3.50 & 1.001 & 4 & 3.72 & 1.058 & 4 \\
\hline Three & 3.32 & 1.002 & 4 & 3.82 & 1.024 & 3 \\
\hline Four & 3.51 & 1.036 & 4 & 3.71 & 1.036 & 5 \\
\hline Five & 3.59 & 1.020 & 4 & 3.70 & 1.128 & 4 \\
\hline Six & 3.83 & 0.937 & 4 & 3.92 & 0.927 & 3 \\
\hline Seven & 2.87 & 1.061 & 3 & 3.18 & 1.048 & 3 \\
\hline Eight & 2.95 & 1.070 & 3 & 3.39 & 1.004 & 3 \\
\hline Nine & 2.43 & 0.937 & 3 & 3.02 & 1.080 & 3 \\
\hline Ten & 2.39 & 1.912 & 2 & 3.08 & 1.201 & 3 \\
\hline Eleven & 3.51 & 1.064 & 4 & 3.70 & 1.199 & 4 \\
\hline Twelve & 2.53 & 1.186 & 3 & 3.21 & 1.230 & 4 \\
\hline Thirteen & 3.15 & 1.073 & 3 & 3.32 & 1.259 & 4 \\
\hline
\end{tabular}

Source: Research results

In general, it can be concluded that the attitude toward whistleblowers and whistleblowing is more positive than the potential reaction of the interviewees. It suggests that the moral belief, in case of whistleblowing, is not strong enough to encourage whistleblowing behavior, due to both Slovakian and Croatian overall experience that whistleblowers are punished without exemptions, and the perception that such efforts will be futile (Mesmer-Magnus and Viswesvaran, 2005). In fact the summary of personal factors that inhibit speaking up can be attributed to the four categories of reasons: a) fear of repraisal/retaliation, b) concern that nothing will be done, c) lack of self-efficacy (the idea that one has confidence/ability to speak up), d) lack of awareness that the behavior is wrong (http://www.ethicalsystems.org/content/whistleblowing. Avaliable on 13. 06. 2017.).

\section{Attitude to whistleblowers, whistleblowing and potential whistleblowers' reaction}

Evaluation of students' attitude towards whistleblowing, whistleblowers, potential external and internal reaction is actualized via basic descriptive statistics for the mentioned variables, presented in the table 6 .

Table 6. Basic descriptive statistics for key whistleblowing variables of Slovakian and Croatian students

\begin{tabular}{|l|c|c|c|c|c|c|}
\hline \multicolumn{1}{|c|}{ Variable } & \multicolumn{3}{c|}{ Slovakian sample } & \multicolumn{3}{c|}{ Croatian sample } \\
\hline & Mean & Mode & Std. Deviation & Mean & Mode & Std. Deviation \\
\hline 1. Total attitude & 3.55 & 3.80 & 0.72 & 3.77 & 3.40 & 0.75 \\
\hline 2. Total reaction & 2.91 & 3.00 & 0.70 & 3.28 & 3.50 & 0.69 \\
\hline 3. Whistleblowers' attitude & 3.44 & 3.33 & 0.80 & 3.75 & 4.00 & 0.78 \\
\hline 4. Whistleblowing attitude & 3.71 & 4.00 & 0.90 & 3.79 & 5.00 & 0.95 \\
\hline 5. Reaction external & 2.66 & 3.00 & 0.89 & 3.16 & 3.00 & 0.85 \\
\hline 6. Reaction internal & 3.15 & 3.50 & 0.88 & 3.40 & 3.00 & 0.98 \\
\hline
\end{tabular}

Source: Research results 
The general (total) attitude to whistleblowing is mostly positive in both samples (Slovakian students: $\mathrm{M}=3.55$, $\mathrm{s}=0.72$; Croatian students: $\mathrm{M}=3.77, \mathrm{~s}=0.75$ ) with mode values of 3.80 and 3.40 for Slovakian and Croatian interviewees respectively. Therefore the both management student samples perceive the importance of whistleblowing and whistleblowers. Substantial difference can be noticed between Slovakian students' attitude to whistleblowing $(\mathrm{M}=3.71, \mathrm{~s}=0.90)$ as a phenomenon and attitude to whistleblowers as individuals $(\mathrm{M}=3.44, \mathrm{~s}=0.80)$. Attitude towards whistleblowing in general is more positive and most of the students who have taken part in the research agree that blowing the whistle is not only a moral right but as well a moral duty of every individual, while they are mostly neutral regarding the role and importance of whistleblowers.

This outcome by the Slovak sample has his possible explanation in the fact that whistleblowers as humans can have different motivations and goals which are not always ethical and quite appropriate. E.g. Heumann at al. 2013 explained whistleblowers with revenge and retribution motives, also bounty hunter motive which want to make money by such an activity. Perhaps by some number of examinees in the Slovak sample perceive "dark side" motivation of some whistleblowers so they are perceived less appropriate than the opinion about abstract phenomenon of whistleblowing.

Croats, on the other hand, do not differ significantly in points of view regarding these two items. Both student samples express sensibly more positive attitude to internal reactions on whistleblowing situations (Slovakian sample: $\mathrm{M}=3.15, \mathrm{~s}=0.88$; Croatian sample: $\mathrm{M}=3.40, \mathrm{~s}=0.98$ ) than actions outside of the organization (Slovakian sample: $\mathrm{M}=2.66, \mathrm{~s}=0.89$; Croatian sample: $\mathrm{M}=3.16, \mathrm{~s}=0.85$ ).

This is according the results of Indian MBA students $(\mathrm{N}=237)$ from two Indian business school where respondents reported significantly higher internal whistleblowing intentions than external whistleblowing intention (Dhamija and Rai, 2017). Those authors also found bad consequences for the company were positively correlated with internal whistleblowing intentions, and that collectivism was positively related with internal whistleblowing intention.

It is interesting that both student groups place external whistleblowing reaction at the lowest grade, which implicates that, in spite of generally positive attitudes towards both whistleblowing as a phenomenon and individual whistleblowers, they show low intention to "blow the whistle outside the organization", but also less propensity to react internally in their own organization. Once again, this affinity can be a result of specific cultural socialization and past experiences that blowing the whistle does not pay off and the whistleblowers atone for their actions, although being both ethically and legally justified.

Such results can be partially explained by specific personality by management students population where is to find some higher Machiavellianism e.g. on Croatian sample (Bogdanović and Cingula, 2015), and also researchers from Aarhus University (Denmark) found that students of economics and management have personalities with higher drive for social domination and power (index.hr, 03.05.2017. according Independent).

So higher Machiavellianism can be expected to be found in economics and management student population through the European area. Namely it is found that high Machs are expected to be less likely to report wrongdoing (Dalton and Rath, 2013). According those researcher on 116 MBA students they found that Machiavellianism is negatively related to whistleblowing.

\section{Answer on the second whistleblowing problem}

The second question of the research is concerned about the students' attitude towards whistleblowing, whistleblowers and potential whistleblowers' reaction with regard to gender. The analysis is carried through finding the statistical differences in all the variables between male and female subjects, that is by performing ANOVA (analysis of variance). Table 7 provides the results of the ANOVA test for both interviewed samples, Slovakian and Croatian students. 
Table 7. Statistical differences in different whistleblowing attitudes with regard to gender (0-female; 1-male) ANOVA of Slovakian and Croatian students

\begin{tabular}{|c|c|c|c|c|}
\hline \multirow[b]{2}{*}{ Variable } & \multicolumn{2}{|c|}{ Slovakian sample } & \multicolumn{2}{|c|}{ Croatian sample } \\
\hline & $\mathbf{F}$ & p-value & $\mathbf{F}$ & p-value \\
\hline One & .037 & .848 & .013 & .911 \\
\hline Two & .360 & .549 & .274 & .602 \\
\hline Three & .007 & .931 & .104 & .747 \\
\hline Four & .204 & .652 & 1.189 & .278 \\
\hline Five & .082 & .775 & 1.160 & .284 \\
\hline Six & .820 & .366 & .105 & .747 \\
\hline Seven & .075 & .784 & .481 & .490 \\
\hline Eight & .067 & .796 & 1.052 & .307 \\
\hline Nine & 1.646 & .201 & .688 & .408 \\
\hline Ten & .347 & .556 & 1.241 & .267 \\
\hline Eleven & .420 & .518 & 2.959 & .088 \\
\hline Twelve & .128 & .721 & 8.367 & .005 \\
\hline Thirteen & .047 & .828 & 10.530 & .002 \\
\hline Whistleblowers' attitude & .086 & .770 & .102 & .750 \\
\hline Whistleblowing attitude & .011 & .915 & 1.378 & .243 \\
\hline Total attitude & .062 & .804 & .635 & .427 \\
\hline Reaction external & .948 & .332 & .859 & .356 \\
\hline Reaction internal & .050 & .824 & 8.280 & .005 \\
\hline Total reaction & .572 & .451 & 6.830 & .010 \\
\hline
\end{tabular}

Source: Research results. Comment: Significant statistical differences are bolded.

The presented results suggest that that statistically significant differences between male and female Slovakian interviewees do not exist in any of the inspected variables. These results reveal that Slovakian student population does not embrace the traditional differences between men and women and their role in business life, which includes attitudes to whistleblowing, whistleblowers and potential reactions in such a situation. On contrary, Croatian students have demonstrated four statistically significant differences $(\mathrm{p} \leq 0.01)$ between male and female interviewees:

(1) Statistically significant difference was identified between female and male participants in question twelve ("I will report to top management or to general management"), where female interviewees $(\mathrm{M}=3.54, \mathrm{~s}=1.11)$ exhibited greater proneness to report to general management $(\mathrm{M}=2.84, \mathrm{~s}=1.44)$.

(2) In question 13 ("I will report firstly to my direct supervisor"), female students ( $M=3.63$, $s=1.16)$ were more likely to report to the direct supervisor than their male colleagues $(\mathrm{M}=2.84, \mathrm{~s}=1.40)$.

(3) Another statistically significant difference was found in the variable of internal whistleblowing reaction, as female interviewees $(\mathrm{M}=3.56, \mathrm{~s}=0.80)$ are more likely to internally report (on any of the four ways described in the questionnaire under items 10-13) than male participants $(\mathrm{M}=3.02, \mathrm{~s}=1.09)$.

(4) Statistically significant difference was also found in total whistleblowing reaction between male and female participants, as female interviewees $(\mathrm{M}=3.38, \mathrm{~s}=0.65)$ have shown to be more likely to express any whistleblowing reaction than male interviewees $(\mathrm{M}=3.03, \mathrm{~s}=0.59)$.

These differences reveal that female students in Croatia have more confidence in the management on all levels, and are also more likely to blow the whistle. This could potentially express a substantial distinction in Croatian cultural factors compared to Slovakian, where no such differences between the genders were proved, because 
one explanation for the Croatian students' results could emerge from greater social consequences of whistleblowing in perceptions of male interviewees as they are expected to provide for their families, which could be jeopardized by losing job in case of whistleblowing.

\section{Answer on the third whistleblowing problem}

The third research problem focuses on the differences in attitudes to whistleblowing, whistleblowers and potential whistleblowers' reaction between students with regard to organizational membership. As well as the previous problem, this is also realized through ANOVA testing. The results are presented in table 8 .

Table 8. Statistical differences in different whistleblowing attitudes with regard to organizational membership (0-No; 1-Yes)/ANOVA of Slovakian and Croatian students

\begin{tabular}{|l|c|c|c|c|}
\hline \multicolumn{1}{|c|}{ Variable } & \multicolumn{2}{c|}{ Slovakian sample } & \multicolumn{2}{c|}{ Croatian sample } \\
\hline One & F & p-value & F & p-value \\
\hline Two & .533 & .466 & .049 & .825 \\
\hline Three & 2.204 & .140 & 2.863 & .093 \\
\hline Four & .294 & .589 & 5.598 & .020 \\
\hline Five & .186 & .667 & .206 & .650 \\
\hline Six & 1.830 & .178 & 2.017 & .158 \\
\hline Seven & .055 & .815 & 3.415 & .067 \\
\hline Eight & .749 & .388 & 5.448 & .021 \\
\hline Nine & 1.452 & .230 & .031 & .862 \\
\hline Ten & .610 & .436 & .111 & .740 \\
\hline Eleven & .042 & .838 & 1.414 & .237 \\
\hline Twelve & 2.273 & .134 & 1.077 & .302 \\
\hline Thirteen & .105 & .746 & 1.115 & .293 \\
\hline Whistleblowers' attitude & .070 & .792 & .398 & .529 \\
\hline Whistleblowing attitude & 1.339 & .249 & 2.774 & .098 \\
\hline Total attitude & .905 & .343 & .922 & .339 \\
\hline Reaction external & 1.555 & .214 & 2.368 & .126 \\
\hline Reaction internal & .298 & .586 & 1.149 & .286 \\
\hline Total reaction & .337 & .562 & .256 & .614 \\
\hline & .000 & .987 & .086 & .769 \\
\hline
\end{tabular}

Source: Research results. Comment: Significant statistical differences are bolded.

The results of the analysis on Slovakian sample show there are no statistically significant differences between students who work beyond study, and those who do not, in any of the tested variables. These conclusions suggest that organizational membership does not alter the perception towards whistleblowing, whistleblowers nor the potential whistleblowers' reaction of the interviewed students.

However, on Croatian student sample, two statistically significant $(\mathrm{p}<0.05)$ and one borderline $(\mathrm{p}=0.067)$ differences have been noticed:

(1) Statistically significant difference was found in question 3 ("Whistleblowers are good for public interest") between participants regarding organizational membership, as those who were members of an organization ( $\mathrm{M}=3.94, \mathrm{~s}=0.96$ ) were more likely to believe whistleblowing is good for the society compared to those who had no work experience $(\mathrm{M}=3.49, \mathrm{~s}=1.08)$, where $\mathrm{p}<0,05$. This implies work experience makes a difference in perception of impact of whistleblowing on social interest and well-being. 
(2) Another statistically significant difference was identified between the interviewees who were and those who weren't organizational members in question 7 ("I will report to the authority outside the organization"). The results suggest that organizational participants $(\mathrm{M}=3.54, \mathrm{~s}=1.00)$ are more likely to whistle outside the organization than the interviewees with no work experience $(\mathrm{M}=3.12, \mathrm{~s}=0.97)$ where $\mathrm{p}<0,05$. This is possible so because organizations where students are working do not allow/have negative attitude on internal whistleblowing, or simply there is missing ethical leadership and co-worker ethical behaviour. Namely, when supervisory ethical leadership and co-worker ethical behaviour are both low the level of reporting should be lowest because multiple social actors are communicating that being ethical is less important (Mayer at al, 2013, 90). Because "non working" students have no such organizational experience, those differences becomes obvious.

(3) Statistical significance of the difference between interviewees who were organizational members compared to those who were not was defined as borderline $(\mathrm{p}=0,067)$ in question 6 ("I will use the information channels outside the organization"). It implies that organizational interviewees ( $M=3.35, s=1.12)$ are more likely to whistle from the outside information channels than their no work experience counterparts $(\mathrm{M}=3.00, \mathrm{~s}=0.94)$. Those results and difference can be explained in the same manner as in point (2).

These differences help us in conclusion that being part of an organization makes the Croatian individuals more aware about the social usefulness of whistleblowing and prone to use external information sources to blow the whistle.

\section{Comparison of Croatian and Slovakian students' attitude to whistleblowing}

\section{Comparison of general remarks on basic descriptive results for all the items}

In the following section, the results of the earlier described research conducted by Bogdanović and Tyll (2016), on a sample of 121 students of management on University of Split, Croatia, will be statistically compared to the study on Slovakian students which was also presented above in the paper and descriptively explained.

While Croatian students demonstrated almost the same positive attitudes towards both whistleblowing $(\mathrm{M}=3,75)$ as a phenomenon and individual whistleblowers $(M=3,79)$, Slovakian students were only positive regarding whistleblowing in general $(M=3,71)$, while neutral to whistleblowers $(M=3,44)$. This could lead to a conclusion that Croatian students have more developed sense of morality and duty to act ethically, but of course this should be tested.

Attitude to potential reaction on whistleblowing situation inside the organization is dominantly neutral in both the Slovakian and Croatian interviewees $(\mathrm{M}=3,15$ vs. $\mathrm{M}=3,40)$. On the other hand, external reaction attitude is between neutral and negative in Slovakian sample $(M=2,66)$, while neutral in Croatian students $(M=3,16)$. These results could possibly suggest that the climate around public whistleblowing, as well as consequences for the whistleblowers, has been more serious and negative in Slovakia, so the students would hesitate to inform the general public and the media.

\section{Comparison of attitudes to whistleblowers, whistleblowing, and potential whistleblowers reaction between Slovak and Croatian sample}

To determine whether there are significant differences in the two student samples, a simple t-test was used to inspect existence of statistically significant differences in means of the two groups. Variables chosen for the comparison were summary variables - attitude to whistleblowers, attitude toward whistleblowing and total attitude, as well as potential internal, external and total whistleblowers' reaction. The values of these parameters for both Slovakian and Croatian student sample, and the results of the test, are shown in table 9: 
Table 9. Results of two-sample t-test for equal means on Slovakian and Croatian student sample

\begin{tabular}{|l|c|c|c|c|c|c|}
\hline \multicolumn{1}{|c|}{ Variable } & \multicolumn{2}{c|}{ Slovakian students } & \multicolumn{2}{c|}{ Croatian students } & \multicolumn{2}{c|}{ t-test } \\
\hline Total attitude & Mean & Std. deviation & Mean & Std. deviation & t & \multicolumn{1}{c|}{ p } \\
\hline Total reaction & 3.55 & 0.72 & 3.77 & 0.75 & -2.504 & $\mathbf{. 0 1 3}$ \\
\hline Attitude to whistleblowers & 2.91 & 0.70 & 3.28 & 0.69 & $-4,476$ & $\mathbf{. 0 0 0}$ \\
\hline Attitude to whistleblowing & 3.44 & 0.80 & 3.75 & 0.78 & -3.302 & $\mathbf{. 0 0 1}$ \\
\hline External reaction & 3.71 & 0.90 & 3.79 & 0.95 & -0.723 & .471 \\
\hline Internal reaction & 2.66 & 0.89 & 3.16 & 0.85 & 4.843 & $\mathbf{. 0 0 0}$ \\
\hline
\end{tabular}

Source: Research results. Comment: Significant statistical differences are bolded.

The results of the two-sample t-test suggest existence of five statistically significant differences between Slovakian and Croatian student groups:

(1) Croatian students $(\mathrm{M}=3.77, \mathrm{~s}=0.75)$ have generally more positive attitude toward whistleblowing and whistleblowers than their Slovakian colleagues $(M=3.55, \mathrm{~s}=0.72), \mathrm{p}<0,05$.

(2) Croatian students $(\mathrm{M}=3.28, \mathrm{~s}=0.69)$ are substantially more likely to react, either internally or externally, in a whistleblowing situation than the Slovakian students $(\mathrm{M}=2.91, \mathrm{~s}=0.70), \mathrm{p}<0,01$.

(3) Croatian interviewees have shown more positive attitude $(\mathrm{M}=3.75, \mathrm{~s}=0.78)$ toward individual whistleblowers than the Slovakian ones $(\mathrm{M}=3.44, \mathrm{~s}=0.80), \mathrm{p}<0,01$.

(4) Potential reaction outside of the organization is significantly more likely to happen in case a Croatian participant were to be in a whistleblowing situation $(\mathrm{M}=3.16, \mathrm{~s}=0.85)$ than in case of their Slovakian counterparts $(\mathrm{M}=2.66, \mathrm{~s}=0.89), \mathrm{p}<0,05$.

(5) Croatian participants have also been found more likely to act inside of their organization if they were in a position to blow the whistle.

Possible causes and explanations for the identified statistically significant differences have been elaborated in the above part of the paper which focuses on general remarks and summary attitudes to whistleblowing, whistleblowing and potential reaction of Slovakian and Croatian students' samples.

\section{General discussion and research limitations}

The most common way of interpreting the differences in attitudes of the two interviewed student samples would be identifying them as mainly cultural. Two most widely studied types of cultural orientation are individualism and collectivism, which are characterized by how much a person stresses his or her own goals, or the goals of his or her group (Triandis, 1995 according to Park et al. 2008). According to the research of Dhamija and Rai, 2017, on 237 MBA students in India it is found that collectivism is positively related with internal whistleblowing intention. These two dimensions' influence on whistleblowing can be seen through general collectivist cultures' disapproval of whistleblowing, since it disrupts the unity of an organization (Brody, Coulter and Mihalek, 1998 according Park et al., 2008). In other words, variability in cultural norms which emphasizes or de-emphasizes loyalty affects the likelihood of whistleblowing (Park et al., 2008).

The results of the research would thus suggest that the Slovakian business community has stronger collectivism than Croatian, which would explain their less positive attitude towards whistleblowers and more positive attitude towards whistleblowing. However, this is contrary to statistically indifferent attitudes to whistleblowing as a phenomenon, which is virtually the same in the both student groups. This leads us to a conclusion that the 
differences in the attitudes towards whistleblowers, as well as potential internal, external and total reactions are not caused by diverse degrees of collectivism, but principally as an effect of the consequences and bad experiences of the individual whistleblowers in the publicly-known whistleblowing cases.

This research showed that even students are not quite free from the social fear of doing whistleblowing, but such freedom of future employee's and executives is very important for future organization and management development. Whistleblowers gives clear signal about the credibility of ethical declaration in organization (Hansmann, 2017), that potentially unethical behavior exist, and potentially unethical behavior of company management (today students, tomorrow executives) leads to the degradation of the ethical behavior of employees and whole organization. Therefore is important to know what future employees feel about the ethical phenomenon of whistleblowing and whistleblowers and potential ways of reporting.

Use of whistleblowing is important ethical organizational management tool - i.e. one of the most important tools for making disclosures and preventing fraudulent and corruptive practices in public administration and in public and private companies. If employees are not afraid to report potential fears and problems, if organization does not tolerate any kind of retaliatory measures against anyone who in good faith reports an alleged breach of obligations or provides any information in relation to an investigation of an alleged breach, and if organization will investigate and punish all potentially measures taken against anyone who reports incorrect behavior (i.e. against whistleblowers), than we can have full benefit of whistleblowing activity (Caha and Urban, 2017). Because humans are valuable assets (humans has infinite value, and their potential is limitless) it is important to treat them with care and dignity (Sikula, 1996, p. 60), whistleblowers are here no exemptions. Therefore if whistleblowers are seen as a valuable element of internal organizational self-control and treated as engaged employees who can secure valuable information and solutions for managerial problems, they could improve both their organization and management.

The strength of the results of the conducted research have methodological limitations, as the students who were chosen as participants may not be representative of the population of the two countries. Another restraint emerges from the self-reported questionnaires which, although anonymous, allow to students to present their attitudes and reactions rather how they would like them to be perceived by the others than how they really are.

\section{Conclusion}

The objective of the research was to measure the attitudes and potential reaction in whistleblowing scenarios of Croatian and Slovakian management students, who represent the future executive population, as well as comparative analysis of the two student samples.

Attitudes towards both whistleblowing as a phenomenon and individual whistleblowers are generally positive in both Slovakian and Croatian participants, with Croatian students' attitudes to whistleblowers has been statistically proven to be significantly more positive. Nonetheless, Croatian students have expressed virtually no differences in their attitudes to whistleblowing as a phenomenon and individual whistleblowers, while their Slovakian colleagues are considerably fonder towards general whistleblowing than the persons who blew the whistle. Potential reason for such result could be that Slovakian participants witnessed bad consequences for the individuals who took part in public whistleblowing affairs and the negative impact it had on the lives of the whistleblowers in question caused fear.

Croatian interviewees have also shown to be significantly more prone to react in a whistleblowing situation both inside the organization and externally via media. These results suggest that the sense of moral duty to blow the whistle, as well as less fear of the potential consequences, is stronger in Croatian students due to cultural differences and moral assets.

The research has shown that both Slovakian and Croatian management students as future executives and leaders value whistleblowing as a positive phenomenon and have general propensity to react if they were to find 
themselves in such a situation. These remarks, in spite of negative experiences and consequences of individuals in famous public whistleblowing cases, imply that whistleblowing cannot be stopped by repressive management methods of punishing whistleblowers. The righteous course of action should be creating a climate in which wrongdoing would be strongly resented and whistleblowers would be deemed as valuable and engaged employees who help in solving managerial problems of the organization. Also it is to propose the creation of supervisory ethical leadership and ethical coworkers (by means of socialization) which would send consistent message supporting ethical behavior and of course internal reporting. This way, organizations could benefit from the fact that most of the whistleblowers are prone to active engagement in correcting wrongdoing, and thus adding more value to their home organizations.

\section{References}

Bjørkelo, B. 2013. Workplace bullying after whistleblowing: Future research and implications. Journal of Managerial Psychology 28(3): 306-323. https://doi.org/10.1108/02683941311321178

Bogdanović, M.; Tyll, L. 2016. Attitude of Management Students Towards Whistleblowing: Evidence from Croatia. Central European Business Review 5(1), 45-61. DOI: 10.18267/j.cebr.144 https://cebr.vse.cz/pdfs/cbr/2016/01/05.pdf

Bogdanović, M.; Cingula, D. 2015. Dark Triad of Croatian Management Students. Central European Business Review 4(4), 30-47. DOI: $10.18267 / j . c e b r .136$ https://cebr.vse.cz/pdfs/cbr/2015/04/04.pdf

Brabeck, M. 1984. Ethical Characteristics of Whistle Blowers. Journal of Research in Personality 18(1), 41-53. https://doi. org/10.1016/0092-6566(84)90037-0

Caha, Z.; Urban, J. 2017. A Code of Ethics as an Organizational Management Tool and its Use in the Czech Republic, Lüdenscheid, Germany: RAM-Verlag.

Chudziska-Czupala, A. E. 2013. Ethical Ideology as a Predictor of Ethical Decision Making. International Journal of Management and Business 4(1), 82-104. https://www.researchgate.net/publication/291355827_Ethical_Ideology_as_a_Predictor_of_Ethical_Decision_Making

Dalton, D.; Radtke, R. R. 2013. The Joint Effects of Machiavellianism and Ethical Environment on Whistle-Blowing. Journal of Business Ethics 117(1), 153-172. http://dx.doi.org/10.1007/s10551-012-1517-x

Dasgupta, S.; Ankit, K. (2010). Whistleblowing: A survey of Literature. The IUP Journal of Corporate Governance 9(4), 1-14. www. academia.edu/976633/Whistleblowing_A_Survey_of_Literature

DeVellis, R. F. 1991. Scale Development: Theory and Applications (Applied Social Research Methods Series, Vol. 26). Newbury Park, CA: Sage Publications.

Dhamija, S.; Rai, S. 2017. Role of Retaliation and Value Orientation in Whistleblowing Intention. Asian Journal of Business Ethics, p. 1-16. First Online: 10 May 2017 https://link.springer.com/article/10.1007\%2Fs13520-017-0078-6 \& https://doi.org/10.1007/s13520017-0078-6

Dungan, J.; Waytz, A.; Young, L. 2015. The Psychology of Whistleblowing. Current Opinion in Psychology, 6, 129-133. https://doi. org/10.1016/j.copsyc.2015.07.005

Kabát, L.; Filip, S.; Filipová, L. 2017. Safety Measurmment Peculiarities in Selected Countries, Journal of security and sustainability issues, 6(3): 343-356. https://doi.org/10.9770/jssi.2017.6.3(2)

Kordík, M.; Kurilovská, L. 2017. Protection of the national financial system from the money laundering and terrorism financing, Entrepreneurship and Sustainability Issues 5(2): 243-262. https://doi.org/10.9770/jesi.2017.5.2(7)

Luzgina, A. 2017. Problems of corruption and tax evasion in construction sector in Belarus, Entrepreneurship and Sustainability Issues 5(2): 263-282. https://doi.org/10.9770/jesi.2017.5.2(8)

Global Economic Crime Survey 2016. Country summary: Key findings in Cyprus - Adjusting the Lens of Economic Crime: Preparation brings opportunity back into focus, PwC June 2016, p. 1-33. https://www.pwc.com.cy/en/events/assets/economic-crime-survey2016-event-presentation-roussos-ellina.pdf

Grimsley, K. D. 2000, June 14. Office Wrongdoing Common, Washington Post, p. E02.

Hansmann, C. A. 2017. Reflective and Ethical Leadership and Management. In: V. C. X. Wang at al., Educational Leadership and Or- 
ganizational Management: Linking Theories to Practice (p. 25-52). USA: Information Age Publishing.

Heumann, M.; Friedes, A.; Cassak, L.; Wright, W.; Joshi, E. 2013. The World of Whistleblowing: From the Altruist to the Avenger. Public Integrity.16(1), 25-51. DOI: 10.2753/PIN1099-9922160102; https://www.tandfonline.com/doi/pdf/10.2753/PIN10999922160102? needAccess $=$ true

KPMG, 2008. Business Codes of the Global 200: Their Prevalence, Content and Embedding. KPMG: Netherlands, p.1-28. http://www. ethicsmanagement.info/contents/Business\%20codes\%20Fortune\%20200.pdf

Lučić, M. 2013. Istina je najvažnija: Intervju s Jackom Hawleyem. [Truth is the most important: Interview with Jack Hawley], qLife znanost i umjetnost liderstva, Tema: Duhovnost u poslovanju [qLife - Journal of leadership science and art, Topic: Spirituality in Business] 5(2), 45-58. file://C:/Users/Mario/Downloads/1380577147qlife19prew.pdf

Luzgina, A. 2017. Problems of corruption and tax evasion in construction sector in Belarus, Entrepreneurship and Sustainability Issues 5(2): 263-282. https://doi.org/10.9770/jesi.2017.5.2(8)

Mayer, D. M.; Nurmohamed, S.; Trevino, L. K.; Shapiro, D. L.; Schminke, M. 2013. Encouraging Employees to Report Unethical Conduct Internally: It Takes a Village. Organizational Behavior and Human Decision Processes 121, 89-103. https://doi.org/10.1016/j. obhdp.2013.01.002

Mesmer-Magnus, J. R.; Viswesvaran, C. 2005. Whistleblowing in Organizations: An Examination of Correlates of Whistleblowing Intentions, Actions, and Retaliation, Journal of Business Ethics, 62: 277-297. https://doi.org/10.1007/s10551-005-0849-1

Miceli, M. P.; Near, J. P.; Dvorkin, T. M. 2008. Whistle-blowing in Organizations. Mahsah, NJ: Taylor and Francis, LEA Organization and Management Series

Miceli, M. P.; Near, J. P. 1984. The Relationships Among Beliefs, Organizational Position, and Whistleblowing Status: A Discriminant Analysis, Academy of Management Journal 27(4), 687-705. DOI: 10.2307/255873; http://www.jstor.org/stable/255873

Near, J. P.; Miceli, M. P. 1996. Whistle-Blowing: Myth and Reality, Journal of Management 22(3), 507-526. https://doi. org/10.1177/014920639602200306

Near, J. P.; Miceli, M. P. 1985. Organizational Dissidence: The Case of Whistleblowing. Journal of Business Ethics, 4(1), 1-16. DOI 10.1007/BF00382668; https://link.springer.com/article/10.1007/BF00382668 \& https://www.researchgate.net/publication/256132631_ Organizational_Dissidence_The_Case_of_Whistle-Blowing

Ottensmeyer, E. J.; McCarthy, G. D. 1996. Ethics in the Workplace. International Edition (New York...Toronto): McGraw-Hill Companies, Inc.

Park, H.; Blenkinsopp, J.; Oktem, M. K.,; Omurgonulsen, U. 2008. Cultural Orientation and Attitudes Towards Different Forms of Whistleblowing: A comparison of South Korea, Turkey and the UK. Journal of Business Ethics, 82(4), 929-939. https://doi.org/10.1007/ s10551-007-9603-1

Pastuović, N. 1999. Edukologija: Integrativna znanost o sustavu cjeloživotnog obrazovanja i odgoja [Educology: Integrative science about the life-long education system], Zagreb: Znamen.

Ridge, P. S. 2000, May 11. Ethics programs aren't stemming employee misconduct, a study indicates. Wall Street Journal, p. A1 (column 5).

Sikula, A., Sr. 1996. Applied Management Ethics, IRWIN: Chicago, Bogota, Buenos Aires, Caracas, London, Madrid, Mexico City, Sydney, Toronto.

Sims, R. L.; Keenan, J. P. 1998. Predictors of External Whistleblowing: Organizational and Intrapersonal Variables, Journal of Business Ethics 17, 411-421. https://doi.org/10.1023/A:1005763807868

Soeken, L. K.; Soeken, R. D. 1986. A Survey of Whistleblowers: Their Stressors and Coping Strategies. p.1-17. http://www.whistleblower-net.de/pdf/Soeken.pdf

Tavakoli, A. A.; Keenan, J. P.; Crnjak-Karanović, B. 2003. Culture and Whistleblowing: An Empirical Study of Croatian and United States Managers Utilizing Hofstede`s Cultural Dimensions. Journal of Business Ethics, (March), 43(1-2), 49-64. http://www.jstor.org/ stable/25074975

Vandekerchove W.; Commers, M. S .R. 2004. Whistleblowing and Rational Loyalty, Journal of Business Ethics, 53(1-2), 225-233. https://doi.org/1023/B:BUSI.0000039411.11986.6b 
Vaysilova E. 2015. Assessment and management of enterprise liquidity in conditions of crisis, The Twenty International Scientific Conference CRISES SITUATIONS SOLUTION IN THE SPECIFIC ENVIRONMENT, Zilina, Slovakia, E.U.; p. 715-720, 20-21 May 2015, ISBN:978-80-554-1023-4

Wu, L.-Z., Yim; F. H.-k., Kwan, H. K.: Zhang, X. 2012. Coping with Workplace Ostracizm. The Role of Ingratiation and Political Skill in Employee Psychological Distress. Journal of Management Studies, 49(1), 177-199. https://doi.org/10.1111/j.1467-6486.2011.01017.x

www. index.hr. (Croatian news e-portal). Available on 03. May 2017. (research cited from Independant) "Ako ste studirali na ovim fakultetima velika je vjerojatnost da ste psihopat" ["If you have studied on this faculties there is a large possibility you are psychopath"]

Večernji list (Croatian newspaper) 2014. "Zviždaču nagrada 10\% od iznosa štete koju je spriječio" ["To the whistleblower the reward in the amount of $10 \%$ of the damage which he prevent"]. Retrieved on February 20, 2016 from http://www.vecernji.hr/hrvatska/zvizdacunagrada-10-od-iznosa-stete-koju-je-sprijecio-920337

Mario Bogdanović, Docent, PhD\&MSc\&BSc Economics, BSc Psychology, senior research associate, has been employed in business, primary, secondary, college study level and from 01 February 2008. to 31 January 2018. on Faculty of Economics University in Split, on the Management Department, Croatia. On the ground of achieved grant of Slovak government was visiting professor, teacher and researcher (docent, senior research associate) at Faculty of Economics Matej Bell University in Banská Bystrica in summer semester 2015./2016. His professional area of interest is general management, human resources management (HRM), organizational behaviour, strategic management, strategies of new product, business ethics, entrepreneurship. He published about 65 scientific and professional papers. As visiting professor he taught also in several European countries in the topics of business ethics, HRM, organizational behaviour, entrepreneurship. He was active in several scientific projects, and was leader for introducing new study programs and courses on master level in the area of organization and management.

Stanislav Filip, Assoc prof. Ing. PhD. is the Vice-Rector for foreign affairs an teacher of the School of Economics and management in Public Administration in Bratislava. His text books, monographs and scientific papers deal with the Risk and crisis managemtn in public sector, international crisis management and public administration at the national and EU level. He is succesfull leader and manager of the several scientific projects with support from the EU structural funds. He also organise and control international colaboration and Erasmus plus program with the high educational and research institutions in abroad.

\section{APPENDIX \\ TOTAL - 13 items}

\section{Attitudes towards whistleblowers}

1. Whistleblowers prevent greater damage to the organization.

2. Whistleblowers are the corruption control.

3. Whistleblowers are good for public interest.

\section{Attitudes towards whistleblowing (ethical correctness)}

4. To blow the whistle is the moral duty of every employee.

5 . To blow the whistle is morally correct.

\section{Whistleblowers' reaction - outside the organization (external)}

6 . I will use the information channels outside the organization.

7. I will report to the authority outside the organization.

8. I will report to NGOs (non-governmental organizations).

9. I will report to public using mass media.

Whistleblowers' reaction - inside the organization (internal)

10. I will report the person of my trust in the organization.

11. I will use internal organizational e-mail to report.

12. I will report to the top management or general management.

13. I will report to my direct supervisor. 